\title{
The multi-dimensional talent support tool (mBET) - a systemic approach towards individualized support of the gifted and talented in Austria
}

\author{
Johanna Stahl*
}

Austrian Research and Support Center for the Gifted and Talented, Salzburg, Austria

\begin{abstract}
Providing gifted students with personalized talent development programs is a challenge for teachers and educators alike. The multi-dimensional talent development tool (mBET) guides teachers on their way to individualized gifted programs. Within a holistic and systemic concept of giftedness, the mBET brings together the perspectives of teachers, parents and the individual student in assessing talents as well as relevant personality characteristics and environment factors. By facilitating support-oriented round-table talks, the mBET helps teachers, parents and students to develop individually tailored talent development programs, taking into consideration both talents and other factors relevant for successful gifted education (i.e. non-cognitive personality characteristics and environmental factors).
\end{abstract}

Keywords: gifted, talented, special needs, education, Austria

\section{Pripomoček za večdimenzionalno podporo talentom (mBET) - sistemski pristop $k$ individualizirani podpori nadarjenim in talentiranim v Avstriji}

\author{
Austrian Research and Support Center for the Gifted and Talented, Salzburg, Avstrija
}

Povzetek: Učiteljem in pedagogom zagotavljanje podpore nadarjenim učencem s personaliziranimi razvojnimi programi predstavlja izziv. Večdimenzionalni pripomoček za razvoj talenta (mBET) vodi učitelje na poti individualiziranih programov za nadarjene učence. Znotraj holističnega in sistemskega koncepta nadarjenosti mBET združuje vidike učiteljev, staršev in posameznih učencev v ocenjevanju talentov, pa tudi ustreznih osebnostnih lastnosti in dejavnikov okolja. Na osnovi svetovalnih pogovorov, ki imajo podporno funkcijo, mBET pomaga učiteljem, staršem in učencem pri razvijanju individualiziranih razvojnih programov za talente, pri čemer upošteva tako talente kot tudi druge dejavnike, ki so potrebni za uspešno izobraževanje nadarjenih (t.j. nekognitivne osebnostne lastnosti in dejavniki okolja).

Ključne besede: nadarjeni,talentirani, izobraževanje, Avstrija

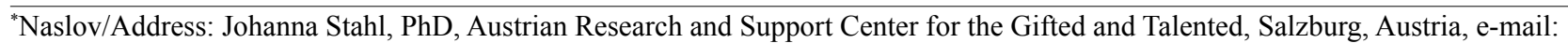
johanna.stahl@oezbf.at

Članek je licenciran pod pogoji Creative Commons Attribution 4.0 International licence. (CC-BY licenca). The article is licensed under a Creative Commons Attribution 4.0 International License (CC-BY license).
} 
The Austrian school system is very differentiated and offers specialized instruction for different ability levels and tracks (Köhler, 2007). Starting from grade 5, students attend schools divided by aspiration level and when entering upper secondary level, students can choose between a variety of academically and vocationally oriented schools. Despite this specialization into different ability levels and interest domains, gifted education (GE) is so far not an integral part of everyday schooling in Austria and is instead often limited to acceleration measures (i.e. early entry to school, skipping grades etc.). Only a few institutions offer specialized instruction for gifted students (i.e. Sir-Karl-Popper-School in Vienna etc.) and enrichment activities for gifted students. Although they are present throughout Austria, they are not centrally coordinated and differ not only in content and duration (i.e. talent courses, summer schools, Olympiads/competitions etc.) or entrance requirements, but also between and even within regions (urban vs. rural areas). As a consequence, there is no general identification and provision program, meaning that gifted and talented students in Austria cannot rely on a widely accessible support system of comparable quality across regions (Fritz, Rosner, \& Rogl, 2014). In line with a generally inclusive approach to education in Austria, efforts in the last years were therefore focused on establishing GE as an integral and natural component of the whole education system, ideally supporting all gifted students in all educational institutions. In this regard, the publication of the white paper (Weilguny, Resch, Samhaber, \& Hartel, 2011) can be rightly seen as a milestone for gifted education in Austria, since it promotes a systemic approach to GE and a holistic concept of giftedness.

In line with the inclusive GE approach of the white paper, the Austrian Research and Support Center for the Gifted and Talented (ÖZBF) developed the multidimensional talent support tool (mBET) which enables teachers in all schools to provide personalized support for individual gifted students in grades 2 to 6 . The mBET offers a teacher-initiated method to assess talents and relevant character and environmental features in a specific student, brings together teachers, parents and the respective students in round-table talks and hence allows for a personalized program of GE. The mBET was developed by the Austrian Research and Support Center (ÖZBF) and embodies a holistic and systemic concept of giftedness and GE according to the Munich Model of Giftedness (Heller, Perleth, \& Lim, 2005) and the Actiotope Model (Ziegler, 2005). The tool consists of various materials and structures the support process in two stages (observation and round-table counselling talk). The mBET includes observation forms (for teachers, parents and students), a profile form, a promotion form and guidelines for support-oriented counselling talks between teachers, parents and students (Rogl, Schmid, \& Stahl, 2013). With the mBET observation form teachers, parents and students can assess talents and school performance of the individual student. In addition, the
mBET observation form also includes character features and environmental factors that are relevant for a successful support program. The mBET profile form combines the observations by teachers, parents and students in one form and therefore facilitates visual comprehension of the different observations. By bringing together these perspectives, the mBET incorporates the viewpoints and perceptions of all participants into the support process and prepares teachers, parents and students alike for transparent round-table talks. These mBET round-table talks serve to bring together different participants with the aim to formulate adequate support measures that are best suited for the talent support of the respective student. The mBET promotion sheet is used to guide the round-table talks and to document the support measures agreed on by teachers, parents and students. Through repeated cycles of observation and regular round-table talks, the mBET allows for continuous talent support of an individual student.

The following paragraphs describe the development and empirical evaluation of the mBET as well as a SWOT analysis of the tool and concluding remarks on the status of the mBET.

\section{The multi-dimensional talent support tool (mBET)}

\section{Development of the mBET}

The mBET is a method for individual talent support. Besides, it also functions as a tool for educational diagnostics, allowing teachers to gather assessments on an individual students' talents, school performance, character features and social environment in order to formulate individualized support measures. This multidimensional perspective of talent support is mainly based on the conceptions of the Munich Model of Giftedness (MMG; Heller et al., 2005), defining giftedness in different domains (i.e. intellectual abilities, creative abilities, social competence etc.) as predictors for aboveaverage performance in various areas (e.g. mathematics, natural sciences, art, languages, athletics/sports etc.). In addition, the MMG stresses the importance of noncognitive personality characteristics and environmental conditions as moderators on the formation processes from potential to performance. In this model, potentials will only then turn into visible performance when flanked by supportive (as opposed to inhibitory) non-cognitive personality characteristics and environmental conditions.

In line with the MMG, the mBET allows for assessment of the following characteristics in a student:

- talent domains:

○ intellectual abilities (vocabulary, verbal comprehension, verbal skills, memory capacity, mathematical comprehension, reasoning, problem perception, problem solving, prior knowledge) 
o physical-kinesthetic abilities (gross motor skills, fine motor skills)

- artistic abilities (perceptual capacity, sculptural and painting abilities, musical abilities, acting abilities, writing abilities)

- creative abilities (creative deductive abilities, imagination, curiosity and exploration, flexibility in perspective, elaboration, diversity of interests)

- school performance

- personality characteristics and environmental factors:

o relationships (building and maintaining relationships, situational adaptation, communication skills, conflict management)

- aspirations and achievement motivation (perseverance, attention, personal initiative, impulse control, willingness for exertion, striving for optimization)

o dealing with demands and challenges (dealing with stress, assessment of own abilities, time management, advance planning, accuracy and diligence, taking over responsibilities)

○ personality (extraversion, stability, optimism, selfassuredness, trustworthiness)

- social integration (social integration, support at school, support at home, support in wider social environment)

The mBET observation form was constructed while taking into account relevant criteria from the ICF-CY (International Classification of Functioning, Disability and Health: Children \& Youth Version; WHO, 2007) and established observation tools and rating scales from the field of gifted education as listed below:

- BFL (Beurteilungshilfen für Lehrer; Janowski, Rauer, \& Fittkau, 1994)

- CBCL 4-18 (Child Behavior Check List; Döpfner et al., 1998)

- GATES (Gifted and Talented Evaluation Scales; Gilliam, Carpenter, \& Christensen, 1996)

- GES (Gifted Evaluation Scale; McCarney \& Arthaud, 2009)

- GRS (Gifted Rating Scales; Pfeiffer \& Jarosewich, 2003)

- HAVEL (Hamburger Verhaltensbeurteilungsliste; Wagner, 1981)

- SIGS (Scales for Identifying Gifted Students; Ryser \& McConnell, 2004)

- SRBCS (Scale for Rating Behavioral Characteristics of Talented and Gifted Students; Renzulli et al., 2002)

- SRBCSS-R (Scales for Rating the Behavioral Characteristics of Superior Students; Renzulli et al., 2013)

Over the course of two years, a preliminary mBET observation scale was continuously tested in the region of Upper Austria and repeatedly adapted, resulting in the final teacher observation form with a total of 48 items in 10 subscales. From the teacher observation form, a parent observation form (slightly modified) and a considerably simplified student self-assessment form were derived. In a series of studies, the mBET observation forms were empirically validated with regards to observer congruence and external validity (Stahl, Rogl, \& Schmid, 2015).

The structure of the roundtable counselling talks proposed for the use of the mBET is inspired by the structures found in classic counselling or coaching settings. It aims to achieve a systemic and sustainable support program for the individual child and is oriented along the basic principles of systemic gifted education according to Ziegler and Stöger (2009): holistic talent development of the whole system, resource orientation, expansion of a person's action repertoire and continuous interaction and reflection on individual learning pathways. The resourceoriented mBET round-table talks reflect this approach and form the centerpiece of the mBET support process. Following a fixed structure (introduction, exploration, solution focus, action plan and conclusion), mBET roundtable talks utilize a variety of negotiation tools and methods (i.e. different question formats, thought experiments/ miracle question, scaling etc.; cf. Rogl et al., 2013). The mBET promotion form is designed for both preparation and documentation of mBET round-table talks. Results from the round-table talks, such as the different measures in the individual support plan, are noted in detail (i.e. goal and description of support measure, person responsible for implementation, indicators for measure's effectiveness) and can be used as a starting point in follow-up roundtable talks. With this stepwise approach, the mBET supports a steady and sustainable support program that is tailored to the individual student's talents and needs, while also taking into account relevant moderating factors (non-cognitive personality characteristics and social environment of the student).

\section{Implementation of the $\mathrm{mBET}$}

Implementing the mBET in Austria is realized through a stepwise distribution process. As using the mBET requires teacher training and qualification, especially in the area of negotiation techniques and counselling talks, the ÖZBF offers regular mBET workshops (free of cost) throughout Austria. Teachers interested in applying the mBET can attend "mBET user" workshops (1.5 days of training). At the time of writing, approximately 160 teachers have completed a "mBET user" workshop and are authorized to use the mBET. Additionally, the ÖZBF offers "mBET multiplicator" workshops for mBET users who themselves are interested in training other colleagues (i.e. in their school) in mBET use. Before becoming mBET multiplicators, interested mBET users need to go through a minimum of two complete mBET support processes. The mBET multiplicator workshops (half-day workshop) are designed to boost knowledge on the mBET, exchange experiences and get feedback on mBET roundtable talks. Participants in mBET multiplicator workshops are especially trained to hold mBET user workshops (i.e. 
within one school or across several schools). With this stepwise distribution and train-the-trainer approach the ÖZBF tries to bring the mBET into local schools all over Austria. The mBET trainings are complemented by a web platform that offers downloads of mBET forms, guidelines and workshop materials as well as exchange forums for mBET users and multiplicators.

\section{SWOT analysis of the mBET}

When looking at the SWOT analysis of the mBET, the following strengths, weaknesses, opportunities and threats can be determined.

\section{Strengths}

The mBET adheres to a systemic approach of gifted education which not only takes into account an individual's talents and potentials, but also looks at the greater environment of an individual student. This approach allows for choosing gifted education measures that best foster the individual's talent development while also taking into account relevant non-cognitive and environmental characteristics.

The multidimensional and dynamic concept of giftedness in the mBET is a holistic concept of giftedness, stressing the importance of a wide spectrum of talents and abilities. With the mBET, intellectual abilities represent just one aspect of giftedness and are complemented by artistic, physical and creative abilities. This holistic concept is in line with research findings and theories stating that noncognitive personality traits (i.e. motivation and positive self-concept) as well as supportive learning environments are more influential and exert a greater prognostic power than above-average intelligence alone.

\section{Weaknesses}

As a bottom-up initiative, the mBET is dependent on the personal initiative and qualification of individual teachers - both with regards to engaging in mBET training as well as providing sensitive and resourceoriented individualized support for gifted students. Since the mBET distribution process has started just one and a half year ago, receiving individualized support (either through mBET or another method) is therefore still a lottery game for students.

The above mentioned problem of (so far) insufficient mBET distribution is complemented by a general lack of counselling for gifted students. Even though there are coordinators for gifted education in all regions (and in some regions even in each district or high school), the demand for counselling far exceeds the supply. School psychologists, who also diagnose and counsel gifted students, are each responsible for up to 10.000 students and have a wide spectrum of responsibilities and clients, including career counselling, motivation problems, eating disorders, $\mathrm{AD}(\mathrm{H}) \mathrm{S}$ and conduct problems.

\section{Opportunities}

The mBET with its systemic approach and holistic concept of giftedness fits into the current "Zeitgeist" of inclusive school policies, the new government program (especially objective "foster talent and gifted pupils - discover and support all gifted pupils and talents"; Austrian Federal Chancellery, 2013, p. 44) and aligns with other recent school requirements (i.e. regular round-table talks at lower secondary schools (NMS) or developmentoriented feedback). This has markedly increased the appeal of the mBET for teachers and educators and has strengthened demand for mBET user workshops and for train-the-trainer offers (mBET multiplicator workshops).

\section{Threats}

Contrary to some of the opportunities mentioned above, the success of the mBET is threatened by a tendency towards more standardization in the Austrian school system. This may result in more homogenous teaching, which may be counteracting individualization and differentiation on the basis of the students' individual strengths and weaknesses.

Furthermore, the educational system continues to be under a lot of stress. Budget cutbacks as well as increasing demands on teachers and a lack of support structures result in an increase of functions that individual teachers have to fulfill and a lack of resources. Voluntary activities such as individualized counselling and gifted programming are at risk of a reduction as teachers encounter a lack of strength and time to offer these services.

\section{Conclusion and outlook}

The mBET comprises a method for individualized gifted support that is initiated by teachers in their classrooms and allows for customized gifted programming for an individual student. With its systemic approach and holistic concept of giftedness, the mBET enables teachers to develop systemic and sustainable talent development measures. By combining the perspectives and viewpoints of teachers, students and parents, all participants take part in the talent development process and share responsibilities for the successful implementation of talent support measures.

By implementing the mBET through distributed mBET user workshops and train-the-trainer approaches, the ÖZBF hopes to stimulate widespread distribution of the mBET. Being a low-threshold instrument for gifted education, the mBET may also aid in sensitizing teachers to a wider spectrum of gifts and talents and improving the effectiveness of gifted education measures through individualized (as opposed to “one-size-fits-all”) programming. 


\section{References}

Austrian Federal Chancellery. (2013). Work programme of the Austrian Federal Government 2013-2018: Austria: A story of success. Retrieved Sept. 03, 2014 from http://www.bka.gv.at/DocView.axd?CobId=53588.

Döpfner, M., Plück, J., Bölte, S., Lenz, K., Melchers, P., \& Heim, K. (1998). CBCL / 4-18: Elternfragebogen über das Verhalten von Kindern und Jugendlichen: Arbeitsgruppe Kinder-, Jugendund Familiendiagnostik [Parent questionnaire on the behavior of children and young people: working group for children, youth and family diagnostics] (2nd ed.). Köln: Arbeitsgruppe Kinder-, Jugend- und Familiendiagnostik.

Fritz,A., Rosner, W., \& Rogl,S.(2014). TalentundBegabung in Österreich [Talent and vocation in Austria]. In M. Stamm(Ed.),Handbuch Talententwicklung: Theorien, Methoden und Praxis in Psychologie und Pädagogik [Manual of Talent Development: Theories, Methods and Practice in Psychology and Education](pp. 303315). Bern, Germany: Huber.

Gilliam, J. E., Carpenter, B. O., \& Christensen, J. R. (1996). Gifted and Talented Evaluation Scales (GATES). Austin, TX, USA: PRO-ED.

Heller, K. A., Perleth, C., \& Lim, T. K. (2005). The Munich Model of Giftedness designed to identify and promote gifted students. In R. J. Sternberg \& J. E. Davidson (Eds.), Conceptions of giftedness (2nd ed., pp. 147-170). New York, NJ, USA: Cambridge University Press.

Janowski, A., Rauer, W., \& Fittkau, B. (1994). Beurteilungshilfen für Lehrer (BFL): Handanweisung für die Durchführung, Auswertung und Interpretation [Assessment tools for teachers: Instructions for implementation, evaluation and interpretation]. Braunschweig, Germany: Westermann.

Köhler, T. (Ed.). (2007). Die begabungsfördernde Gliederung des österreichischen Schulwesens: Begabtenförderung und Begabungsforschung in Österreich: Bilanz und Perspektive: 1996-2006 [The division for talent promotion in Austrian Education: Gifted and Talent Research in Austria: Balance and perspective: 1996-2006] (p. 11). Wien, Austria: Bundesministerium für Unterricht, Kunst und Kultur.

McCarney, S. B., \& Arthaud, T. J. (2009). Gifted Evaluation Scale Third Edition (GES-3). Columbia, MO, USA: Hawthorne.

Pfeiffer, S. I., \& Jarosewich, T. (2003). Gifted Rating Scales (GRS). San Antonio, TX, USA: The Psychological Corporation.

Renzulli, J. S., Smith, L. H., White, A. J., Callahan, C. M., Hartman, R. K., \& Westberg, K. L. (2002). Scales for Rating the Behavioral Characteristics of Superior Students: Revised Edition. Mansfield Center, CT, USA: Creative Learning Press.
Renzulli, J. S., Smith, L. H., White, A. J., Callahan, C. M., Hartman, R. K., Westberg, K. L., ... Sytsma, R. E. (2013). Scales for Rating the Behavioral Characteristics of Superior Students (Renzulli Scales). Waco, TX, USA: Prufrock.

Rogl, S., Schmid, F., \& Stahl, J. (2013). Lösungsorientierte Gesprächsführung mit dem mBET: Leitfaden für ein Fördergespräch [Solution-oriented conversation with the MBET: Guidelines for a conveyor week]. Salzburg, Austria: ÖZBF.

Ryser, G., \& McConnell, K. (2004). SIGS Scales for Identifying Gifted Students. Waco, TX, USA: Prufrock.

Stahl, J., Rogl, S., \& Schmid, F. (2015). Das multidimensionale Begabungs-Entwicklungs-Tool (mBET): Manual [The multi-dimensional talent development tool (MBET): Manual]. Manuscript in preparation.

Wagner, H.(1981). Hamburger Verhaltensbeurteilungsliste (HAVEL). Göttingen, Germany: Hogrefe.

Weilguny, W. M., Resch, C., Samhaber, E., \& Hartel, B. (2011). Weißbuch:Begabungs-undExzellenzförderung. Salzburg, Austria: ÖZBF.

WHO. (2007). International Classification of Functioning, Disability and Health: Children \& Youth Version (ICF-CY). Geneva: WHO.

Ziegler, A. (2005). The Actiotope Model of Giftedness. In R. J. Sternberg \& J. E. Davidson (Eds.), Conceptions of Giftedness (2nd ed., pp. 411-436). New York: Cambridge University Press.

Ziegler, A., \& Stöger, H. (2009). Begabungsförderung aus einer systemischen Perspektive, [Gifted education from a systemic perspective]. Journal für Begabtenförderung, 9, 6-31. 